\title{
European Integration in the 1980s: on the Way to Maastricht?
}

\section{N. Piers LUDLOW}

The Maastricht Treaty emerged out of one of the most tumultuous periods of recent European history. In the course of the two years preceding the December $1991 \mathrm{Eu}-$ ropean Council at which the intergovernmental negotiations were concluded and the treaty text finalised, the whole international context of the European Community had been transformed most notably by the end of the Cold War, the disappearance of the Iron Curtain and the unification of Germany. In between the Maastricht Council and the signature of the Treaty in February 1992, moreover, a further geo-political earthquake would occur, with the dissolution of the Soviet Union. Little wonder then that many observers have speculated on the effect that this remarkable series of events had on the shape of the European agreements concluded amongst the Twelve EC member states. Particular attention has been paid to the supposed connection between French acquiescence in German unification, and German acceptance of France's desire for rapid progress towards Economic and Monetary Union (EMU), the core component of the Maastricht Treaty. As David Marsh puts it:

'the fusing of the two Germanys, and the birth of the single currency, are intimately intertwined. If unification had not happened, it is highly unlikely that France would have been able to persuade [German Chancellor] Kohl to agree the EMU timetable to replace the D-Mark by the Euro'. ${ }^{1}$

This article does not seek to reject entirely the link between the Maastricht Treaty and the geo-political revolution of 1989-91. As other contributors to this special issue will make clear, the intra-European politics of 1989-91 were crucial in determining the exact shape and timing of the Treaty, and such politics could not but be influenced by the end of the Cold War and the transformation of Germany. It will however suggest that as important, if not more important, in determining the fundamental shape and contents of the 1991 Treaty, as well to some extent its timing, was the longer term trajectory of European integration, stretching back at least as far as the early 1980 s, if not further. No complete explanation of what happened amongst the Twelve in 1990-91 is possible without extensive acknowledgement of the trends and directions of the integration process that had developed during the preceding decade. Multiple pressures for extensive Treaty change had already accumulated by early 1989 and it was hence always likely that many in Brussels and beyond would be campaigning for radical advance in the years that followed, albeit with no absolute guarantee of having all of their ambitions fulfilled. To put it slightly differently, 'Europe' was on the move well before the geo-political transformations of November 1989 onwards.

1. D. MARSH, The Euro: the politics of the new global currency, Yale University Press, New Haven, Conn./London, 2009, p.133. 
In order to demonstrate the importance of the legacy of the 1980s, this article will focus on four different 'trends' that had emerged during the decade each of which fed through into the Maastricht debates. These trends are first the importance of treaty change as opposed to less formalised advance, second the desire to 'tidy up' those aspects of the integration process that had initially begun outside of the formal Community context, third the ever greater faith in institutional change as a means cope with the EC's constantly expanding range of tasks and challenges, and fourth a tendency towards policy spill-over. Each of these will be looked at in turn, before a concluding section which will return to the issue of how important these longer term pressures and trends would turn out to be.

\section{The irresistible rise of belief in Treaty change}

Over the last twenty five years or so the history of European integration has been punctuated by repeated instances of treaty change. Indeed an author contemplating a historical overview of the process might well be tempted - unwisely perhaps - to organise his or her findings in a series of chapter titles that reflect these institutional milestones: so a section on 'From the Single European Act to Maastricht' would be followed by one covering 'From Maastricht to Amsterdam', the next would take the story from Amsterdam to Nice, and so on all the way through to the 2007 Treaty of Lisbon or perhaps even the recent fiscal pact. Treaty change has, in other words, become a regular occurrence and one seen by many as an essential feature of any significant alteration in the way that 'Europe' functions. ${ }^{2}$

This has not always been the case, however. For the first two decades of the Community's evolution most of the major changes in the way in which the system operated took place without formal treaty modification and its accompanying features of intergovernmental conferences, formal signing ceremonies and (lately at least) fraught ratification processes. There were, it is true, a number of treaty changes during the 1960s and 1970s. These included the 1965 Merger Treaty, the 1970 Luxembourg Treaty modifying the Community's financial base, and the 1975 Brussels Treaty which constituted another attempt to do the same. ${ }^{3}$ Each enlargement of the Community's membership moreover was accompanied by the signature and ratification of a treaty of accession. ${ }^{4}$ But none of these treaty changes covered the really important modifications in the way that the Community was actually run. Instead, the gradual

2. T. CHRISTIANSEN, G. FALKNER, K.E. JØRGENSEN, Theorizing EU Treaty Reform: Beyond Diplomacy and Bargaining, in: Journal of European Public Policy, 1(2002), pp.12-32.

3. See R. MAUGUIS, R. PELLOUX, J.-P. LASSALE, Le Traité de Bruxelles du 8 avril 1965 relatif à la fusion des institutions des Communautés Européennes, Éd. de l'AGEL, Lyon, 1968; B. LAFFAN, The finances of the European Union, Macmillan, Basingstoke, 1997, p.7.

4. J.-P. PUISSOCHET, L'élargissement des Communautés européennes; présentation et commentaire du traité et des actes relatifs à l'adhésion du Royaume-Uni, du Danemark et de l'Irlande, Éditions techniques et économiques, Paris, 1974. 
growth of Council power that occurred during the 1958-69 period, the emergence of the European Council as the Community's most senior decision making body, and the move towards the direct election of the European Parliament happened without treaty sanction (even if this last had been provided for in the Treaty of Rome).$^{5}$ Calls for more formalised reform - such as that issued by the Belgian Prime Minister Leo Tindemans in 1975 - had, by contrast, not come to fruition. ${ }^{6}$

By the early 1980s this process of informal change was widely (if probably unjustly) perceived as one of the roots of the Community's malaise. A crucial way out of the doldrums in which the integration process seemed stuck was thus logically seen as being far-reaching institutional change, carried out through a formal re-writing of the treaties. Gaston Thorn, the President of the European Commission, for example used the occasion of the 25th anniversary of the Treaties of Rome in March 1982 not only to decry the trend towards institutional innovation 'on the fringes of the Treaties, if not entirely outside them', but also to call for 'a new Messina Conference in this the Treaties' jubilee year'. ${ }^{7}$ Of particular importance in this connection was the way in which such treaty change might allow an increase in the use of majority voting an issue to which we will return below. But above and beyond this obsession with majority voting, treaty change more generally came to be seen as the means to break the policy and institutional deadlock in which the EEC of the early 1980s seemed to be trapped. The path from the Genscher-Colombo proposals of 1981 which envisaged institutional change but shied away from formal treaty alteration, to the Stuttgart Declaration of 1983, and then onto the deliberations of the Dooge Committee of $1984-85$, is thus marked by an ever growing conviction amongst most of those eager to see renewed Community dynamism, that such a revival could only come about were the treaties to be modified. ${ }^{8}$ The groundwork for the famous and controversial decision at the Milan Council of June 1985 to convene an intergovernmental conference (IGC) and to begin work on what would become the 1986 Single European Act (SEA) had been laid in a debate stretching right across the first half of the 1980s. ${ }^{9}$

The association between treaty change and Community advance had then been massively strengthened by the perceived success of the Single European Act. The new treaty had not immediately been hailed as a breakthrough. The Economist had been typically dismissive, almost certainly reflecting a British governmental view

5. For the first see N.P. LUDLOW, The European Community and the Crises of the 1960s: Negotiating the Gaullist Challenge, Routledge, London, 2006, pp.118-124; for the second, see E. MOURLONDRUOL, Filling the EEC Leadership Vacuum? The Creation of the European Council in 1974, in: Cold War History, 3(2010), pp.315-339; and the third, see V. HERMAN, J. LODGE, Democratic Legitimacy and Direct Elections to the European Parliament, in: West European Politics, 2(1978), pp.226-251.

6. http://www.cvce.eu/viewer/-/content/03f0d181-4838-4a86-a1b5-f143bb34cbd0/fr (last accessed 22.08.2012).

7. For the text of the speech, http://aei.pitt.edu/12502/ (last accessed 22.08.2012).

8. A.L. TEASDALE, The Life and Death of the Luxembourg Compromise, in: JCMS: Journal of Common Market Studies, 4(1993), pp.571-575.

9. On Milan see A. MORAVCSIK, The Choice for Europe: Social Purpose and State Power from Messina to Maastricht, UCL Press, London, 1999, pp.363-364. 
that they had successfully rid the treaty text of most of its most radical elements. ${ }^{10}$ But Commission President Jacques Delors had also had his doubts, airing these to the European Parliament in a highly cautious speech outlining the results of the IGC. ${ }^{11}$ By the late 1980s, however, all such uncertainty had disappeared and there appeared a near consensus that the treaty had fundamentally transformed the manner in which the Community operated, had dramatically freed up its decision-making processes and was hence at the heart of all the far-reaching policy advances that characterised the final years of the decade. That the subsequent behaviour of the most high profile opponent of treaty change in 1985, Margaret Thatcher, had also demonstrated the depth of her opposition to radical integration, only reinforced the association between treaty change and pro-Europeanism since it suggested that those against treaty change were also fundamentally Euro-sceptic. ${ }^{12}$ By the late $1980 \mathrm{~s}$ it had thus become axiomatic that if Europe was to become more integrated it needed to do so by means of formalised treaty change. The very nature of the process that was to culminate in Maastricht in December 1991 was hence deeply shaped by this 'lesson'.

\section{The desirability of tidying up informal change}

Closely related to this belief in treaty change as an essential component of any move towards 'ever closer union', was an equally strong belief that steps already taken outside of the treaty framework should, if at all possible, be brought back within the formal structures. Although this was not a new phenomenon - the Merger Treaty in the 1960s had been used to retrospectively sanction the establishment of the Committee of Permanent Representatives (COREPER) for instance despite the fact that this had been a key component of the Brussels machine ever since $1958^{13}$ - it was once more an urge that had become very apparent with the SEA and had been strengthened still further by that treaty's success.

The two main types of 'tidying up' carried out by the SEA related to the European Council and to European Political Cooperation (EPC), the mechanism for foreign policy coordination amongst EC member state governments. Article 2 of the Act had thus provided the first formal recognition of the European Council's place within the

10. The Economist, 21.12.1985; for their admission that the 'mouse of reform born at last December's EEC summit is squeaking louder than expected', see The Economist, 08.11.1986.

11. Annex to the Official Journal of the European Communities. Debates of the European Parliament, 1985-86 Session, Report of Proceedings from 9 to 13 December 1985, pp.124-128.

12. For Thatcher's trajectory, see S. WALL, A Stranger in Europe: Britain and the EU from Thatcher to Blair, Oxford University Press, Oxford, 2008, pp.62-107.

13. N.P. LUDLOW, Mieux que six ambassadeurs. L'émergence du COREPER durant les premières années de la CEE, in: L. BADEL, S. JEANNESSON, N.P. LUDLOW (eds). Les Administrations nationales et la construction européenne. Une approche historique (1919-1975), Peter Lang, Brussels, 2005, p.337. 
Community system, although it did little to specify either the extent of its powers or the centrality to the integration process that it had already acquired. ${ }^{14}$ Title III of the treaty meanwhile placed the EPC process on a more official Community footing, bringing inside the formal institutional system a series of intergovernmental mechanisms that had inhabited a strange legal penumbra ever since their creation in the early 1970s. In the process, the Commission's role within the EPC mechanisms for foreign policy coordination was legally affirmed - the culmination of a lengthy pitched battle between France and most of its partners on this issue. ${ }^{15}$ In neither case was the treaty in any real sense altering the status quo. Rather it was retrospectively ratifying a series of arrangements that had emerged informally over the previous decade and a half.

This same basic pattern was at its most evident in the Justice and Home Affairs element of the Maastricht Treaty - the eventual pillar three. Here the informal realities that Maastricht would begin to acknowledge were the development of police cooperation across Europe underway since the mid-1970s in the so-called Trevi Process and the push to eliminate border and passport controls within Europe that had started with the signature of the Schengen Treaty between France, Germany, Belgium, Luxembourg and the Netherlands in June 1985 . Neither of these were originally Community policies, as the highly restricted initial membership of the Schengen group underlined. The signatories of this last had not believed that their ambitions of eliminating border controls completely stood much chance of realisation within the wider EC. Nor, by the late 1980s, had the process of implementation yet gone very far. Indeed the Schengen Convention, setting out the manner in which the original agreement would be translated into actual practice, was only signed in 1990 this time by seven states (Spain and Portugal having joined the original five signatories), with implementation only picking up speed in the mid-1990s. ${ }^{16}$ Similarly, the Trevi process was carried on outside of the Community framework, involving structures that echoed those of the EC Council of Ministers, but with no equivalents of the Commission, the European Parliament or the European Court of Justice. ${ }^{17}$ But the very existence of these extra-Community instances of integration provided an incentive for the Community itself to begin discussing these issues more formally and to assess the extent to which these policy initiatives could be brought 'in-house'. Trevi and Schengen would thus provide one of two important stimuli to the debate that was to emerge in the run up to Maastricht about how to bring within the EC framework a series of policy areas - border control, police cooperation, immigration - that had traditionally been little affected by the integration process.

14. http://ec.europa.eu/economy_finance/emu_history/documents/treaties/singleuropeanact.pdf (last accessed 23.08.2012).

15. A. ROMANO, From Détente in Europe to European Détente: How the West Shaped the Helsinki CSCE, Peter Lang, Brussels, 2009, pp.160 f.

16. V.HREBLAY, Les accords de Schengen: origine, fonctionnement, avenir, Bruylant, Brussels, 1998.

17. F.R. MONACO, Europol: The Culmination of the European Union's International Police Cooperation Efforts, in: Fordham International Law Journal,19(1995), pp.268-269. 


\section{The need for institutional innovation}

A third major 'lesson' of the 1980s was the perceived necessity of pushing ahead with the institutional innovations introduced by the SEA. Crucial to the latter's success had been the introduction of majority voting for all internal market related legislation. This change had been widely - if inaccurately - credited with breaking the deadlock which was meant to have beset the Community ever since the Luxembourg Compromise of $1966 .{ }^{18}$ And it had certainly transformed the behavioural patterns of Ministers and other national representatives discussing policy change in Brussels, creating the expectation amongst them that meetings were likely to produce a legislative outcome rather than impasse, and thereby providing a major incentive for constructive policy proposals instead of stonewalling. The speed of decision making was increased as a result. ${ }^{19}$ It therefore followed - from the point of view of European enthusiasts at least - that any new round of treaty change had to extend this successful innovation to other policy fields also. The Commission had already flirted with controversy at several points in the late 1980s by trying to push through legislation that was only tangentially related to the internal market using the new, post-SEA legal base. ${ }^{20}$ An extension of majority voting to a range of further policy areas would remove the need for such procedural legerdemain. This was all more necessary given the likelihood, discussed below, that the policy domain of the Community would substantially increase. More policy areas would mean more legislation, and more legislation would only be possible were the productivity of the institutional system increased across the board rather than solely on issues concerning the Single Market.

Similarly, there was extensive support for a further increase in the powers of the European Parliament in any new treaty. The cooperation procedure introduced for Single Market legislation by the SEA had been well received, both by European parliamentarians themselves, and by the many partisans of a stronger EP within national governments and elsewhere. But this increase in parliamentarians' influence had only whet the appetite of MEPs and their numerous backers for further movement in the same direction. After all the more active Europe of the late 1980s only aggravated the concern surrounding the 'democratic deficit' - the more Europe did, the more worrying was the lack of a strong democratic component within the Community system - and increased the need for an increase in the EP's role that went beyond the

18. For a debunking of the causal link between the 1966 deal and later deadlock, by one of the key negotiators at the original Luxembourg meeting, see R. LAHR, Die Legende vom "Luxemburger Kompromiß”, in: Europa Archiv, 38(1983), pp.223-232.

19. A detailed debate has erupted between political scientists as to whether decision making was actually faster: see J. GOLUB, In the Shadow of the Vote? Decision Making in the European Community, in: International Organization, 4(1999), pp.733-764; H. SCHULZ, T. KÖNIG, Institutional Reform and Decision-making. Efficiency in the European Union, in: American Journal of Political Science, 4(2000), pp.653-665. Few participants at the time, however, doubted that the process had become more efficient.

20. UK May Challenge EC Powers, in: Financial Times, 17.05.1989. 
welcome but inadequate first step taken in the SEA. ${ }^{21}$ Again therefore any new European treaty was likely to have to go some way in meet this demand, despite the ongoing reticence of certain member states, notably the British and the French. On the powers of European Parliament as with majority voting, the successor treaty of the SEA would be expected to repeat and extend the successes of the SEA itself.

Another innovation, this time not foreshadowed by the SEA, that any new European treaty would have to pay heed to was the notion of subsidiarity. This idea had begun its migration from Catholic social teaching to European affairs in the mid-1970s, first cropping up in the discourse of the Christian Democrats within the European Parliament. By the late 1980s, however, it had begun to feature in European Community debates at Council of Ministers level, promoted by an odd alliance between German Länder, anxious to avoid their powers being eroded by a supranational level of governance over which they had scant control, and those member states, notably the United Kingdom, most apprehensive about too much new intervention by Brussels. Its prospects of actually being incorporated in any treaty text - which would of course happen with the Maastricht Treaty - were vastly improved however by the fact that it could be used both as a mechanism to allay the fears of those anxious about undue EC power and as a justification for Community action in those instances where actions by individual member states were unlikely to prove effective. Its early uses in the 1970s had indeed all been in the context of appeals for greater rather than lesser European powers. ${ }^{22}$ Subsidiarity, in other words, could be a justification for integration, as well as a protection against too much central control. More relevant for this article, however, is the fact that yet another prominent feature of the Treaty of European Union was already part of the European landscape well before the Berlin Wall came down.

\section{Policy spill-over}

The fourth and final trend that links the late 1980s with the shape and agenda of the Maastricht Treaty, is the way in which the policy achievements of the later 1980s the Community's boom years - created substantial pressures for further integration in related areas. The late $1980 \mathrm{~s}$, to put it slightly differently, saw the re-emergence of the notion of spill-over as a mechanism of Community development. This idea, much touted by the neo-functionalists during that earlier period of rapid Community advance, the 1960s, had been attacked and discredited by Stanley Hoffmann in a

21. B. RITTBERGER, Building Europe's Parliament: Democratic Representation Beyond the Nationstate, Oxford University Press, Oxford, 2005, pp.177-186.

22. K. van KERSBERGEN, B. VERBEEK, The Politics of Subsidiarity in the European Union, in: JCMS: Journal of Common Market Studies, 2(1994), pp.215-236. 
celebrated 1966 article; by the late 1980s, it seemed to have re-emerged from its grave. ${ }^{23}$ And this revival would have major implications for the subsequent contents of the Maastricht Treaty.

The most straightforward instance of previous policy advances creating strong pressure for further policy change occurred in the field of monetary integration. For most of the 1980s the majority of European Community member states had grown accustomed to membership of the European Monetary System (EMS). This was generally credited with both avoiding the violent intra-European exchange rate fluctuations of the 1970s and bringing inflation under control across the continent. ${ }^{24}$ But the success of the EMS was grounded in part on the existence of capital controls in a number of the weaker currency countries, which allowed governments to limit the outflow of money, thereby making it much easier for their currencies to remain within the exchange rate fluctuation bands prescribed by the monetary regime. These capital controls, however, were a clear violation of the free movement of capital, one of the four freedoms at the heart of the Single Market Programme. In the course of the late 1980s, therefore France, Italy and several other countries were obliged to abolish their laws on capital exports, bringing closer the realisation of the 1992 target for a fully operational internal market, but also seriously endangering their capacity to remain within the EMS. Advance in one area, posed a direct threat to integration in another equally crucial aspect of integration.

European policy makers were most clearly alerted to this potential problem by the publication of Efficiency, Stability and Equity, a Commission-sponsored report produced by a committee chaired by the eminent Italian economist Tommaso PadoaSchioppa in 1987. ${ }^{25}$ This made use of the Mundell-Fleming 'impossible trinity' model to argue that Europe could not aspire to have free movement of capital, fixed exchanged rates, and national macro-economic freedom all at the same time. Up until the late 1980s, the EMS had sought to balance the last two while forsaking the first. But with the abolition of capital controls either fixed rates or macro-economic freedom would have to be abandoned instead. Translated into policy terms this meant that Europe faced an imminent policy dilemma. Either it could step off the path towards monetary integration it had successfully followed since 1979, or it could push ahead towards tighter integration, at the expense of national macro-economic freedom. This second option would not necessarily require a single currency - the Padoa-Schioppa report remained non-committal on this issue - but it was already clear that with currency controls slated for removal, the current monetary status quo was unsustainable.

23. S. HOFFMANN, Obstinate or Obsolete? The Fate of the Nation-State and the Case of Western Europe, in: Daedalus, 01.07.1966, pp.862-915; J. TRANHOLM-MIKKELSEN, Neo-Functionalism: Obstinate or Obsolete? A Reappraisal in the Light of the New Dynamism of the EC, in: Millennium - Journal of International Studies, 03.01.1991, pp.1-22.

24. D. GROS, N. THYGESEN, European monetary integration from the European monetary system to economic and monetary union, Longman, London, 1998.

25. T. PADOA-SCHIOPPA, COMMISSION of the EUROPEAN COMMUNITIES, Efficiency, stability, and equity: a strategy for the evolution of the economic system of the European community: a report, Oxford University Press, Oxford/New York, 1987. 
And given the widespread sense that monetary integration so far had been beneficial and that a return to the volatility of the 1970s was highly undesirable, the most likely course out of the dilemma would be a move towards greater monetary integration. The intellectual case for the EMU component of the Maastricht Treaty had therefore been set out even before the convening of the Delors Committee on economic and monetary union in $1988 .{ }^{26}$

The other equally clear-cut instance of policy advance in one area creating strong pressures for further integration elsewhere concerns what would become the Justice and Home Affairs portion of the Maastricht Treaty. Here too the trigger factor was the planned Single Market. Establishing a truly unified European market, most member states felt, would involve a substantial scaling down of, if not the total abolition of most border controls and checks. This would facilitate commerce and also offer a visible sign of integration to the wider population. In the new Europe, crossing frontiers, whether for tourists or for those doing business, would no longer involve long queues for border checks. ${ }^{27}$ But the removal of barriers to cross border travel would also have knock-on effects on immigration control, visa policy, the fight against crime, and the limitation of movement of drugs and other illegal products, since in all of these cases national border controls were a central element in existing policy. Shorn of their national border controls, European states would have no option but to cooperate much more closely, establish joint or at least coordinated approaches on all of these issues, encourage interaction and cooperation between customs services, police forces and immigration officials, and pool resources so as to reinforce the strength of the Community's outer borders since these would now constitute the last barrier between the outside world and Europe's border control-free interior. ${ }^{28}$ The planned Single Market thus combined with the pre-existing pressures connected with the Schengen Treaty and the Trevi process discussed above, to help create momentum towards what would become in due course the Justice and Home Affairs pillar of the Maastricht Treaty.

The final example of spill-over is less direct, but too important nonetheless to exclude, since it contributed to the emergence of the second pillar of the eventual treaty, dealing with a common foreign and security policy or CFSP. The basic desire to see Community Europe better able to 'speak with one voice' on foreign policy issues was of course nothing new. Attempts in this direction could be traced back to the Fouchet Plan of 1961 if not earlier. ${ }^{29}$ Nor was dissatisfaction with the inadequacies of the EPC process, in existence since the early 1970s. Despite some low-key successes, this last had not brought about the degree of coordination between the external

26. For a detailed account of the work of the Delors's committee, see H. JAMES, Making the European Monetary Union, Belknap Press, Cambridge Mass., 2012, pp.210-264.

27. It is revealing that the over-zealous removal of border controls was one of the many facets of integration attacked by Margaret Thatcher in her 1988 Bruges speech. For the text of the speech, see http://www.margaretthatcher.org/document/107332 (last accessed August 28, 2012).

28. J. MONAR, The Dynamics of Justice and Home Affairs: Laboratories, Driving Factors and Costs', in: JCMS: Journal of Common Market Studies, 4(2001), p.754.

29. G.-H. SOUTOU, Le général de Gaulle, le plan Fouchet et l'Europe, in: Commentaire, 1(1990). 
relations of European powers that many had initially hoped for. ${ }^{30}$ The GenscherColombo plan of 1981 referred to above had been one of several unsuccessful attempts to remedy its failings. But this underlying level of discontent had been massively accentuated by the general surge forward of the integration process in the late 1980s. If all other aspects of integration were advancing - as seemed to be the case in the latter stages of the decade - the halting progress of EPC was especially frustrating. And the contrast was made even starker by the huge amount of external commercial leverage that the Community in general and the Commission in particular had been able to exercise in the context of the major world trade talks of the period, namely the Uruguay Round of the General Agreement on Tariffs and Trade (GATT). Within the context of the global trade forum, the newly revitalised European Community had been very much at the centre of attention, with the Commissioners involved, Willy de Clerq and then Frans Andriessen for external affairs, Andriessen and then Ray MacSharry for agriculture, able to exercise an influence and clout rivalled only by the US Trade Representative. ${ }^{31}$ This appeared to demonstrate that when Europe was able to act collectively on a world stage it could exercise the type of power and influence that no single Western European country had been able to deploy since the end of the Second World War. The incentive to try and create mechanisms and structures that would give the Community comparable influence in foreign policy matters that stretched beyond trade and agriculture grew significantly as a result. The policy successes of the late 1980s thus added fuel to a pre-existing policy debate, and helped create the conditions out of which pillar two of the Maastricht Treaty would eventually be born.

\section{A foreseeable agenda; an unforeseeable outcome}

None of the trends and pressures outlined above predetermined the exact features of the Maastricht Treaty. Apart from anything else, the depth and sophistication of the discussions about different aspects of what would become the Maastricht agenda varied widely. The debate about EMU, for instance, could not only draw upon a back catalogue of academic and policy-related debate stretching back to the 1970s if not earlier, but had also been pushed forward by a succession of official study groups, most recently those chaired by Delors and bringing together multiple central bank governors and economists. ${ }^{32}$ Discussions about the precise implications of lowering

30. D. MÖCKLI, European Foreign Policy During the Cold War: Heath, Brandt, Pompidou and the Dream of Political Unity, I.B. Tauris, London, 2009.

31. S. MEUNIER, Trading voices: the European Union in international commercial negotiations, N.J. Princeton University Press, Princeton, 2005, pp.102-124.

32. For a sense of monetary debates within the 1970s, see E. MOURLON-DRUOL, A Europe made of money: the emergence of the European Monetary System, Cornell University Press, Ithaca, N.Y., 2012; on the Delors committee, see K.H.F DYSON, K. FEATHERSTONE, The Road to Maastricht: negotiating Economic and Monetary Union, Oxford University Press, Oxford/New York, 1999, pp. 691-745; H. JAMES, op.cit. 
national frontier controls were by contrast much less advanced. There was hence no certainty that the Twelve would try to tackle all of these issues in a single treaty, as opposed to spreading them out over the ten to fifteen years ahead.

The likelihood of gradual advance was also increased by the very wide spread of member state opinions on all of these matters. Britain apart there probably was a consensus by 1989 that more 'Europe' - i.e. further integration - was both necessary and desirable. ${ }^{33}$ There was also agreement that the debate was urgent and that advances would need to be made sooner rather than later. Some sort of intergovernmental conference in the early 1990s and subsequent treaty reform was already very much on the cards. But views on the exact shape, timing and nature of these further European measures varied immensely from member state capital to member state capital, and indeed amongst individual officials and politicians within each national government. Forging agreement from so diverse a range of opinions would not be an easy task. Forging agreement quickly, and creating a far-reaching Treaty of European Union, within a couple of years would be harder still.

All of this means that there is plenty of scope for historians seeking to explain what happened at Maastricht to highlight the role and importance of the precise politics of 1989-1991, and, more fundamentally, the impact of the extraordinary geopolitical transformation of Europe that occurred from 1989 onwards. The liberation of Eastern Europe, the fall of the Berlin Wall, and the ending of that Cold War framework within which the whole European construction had been built, would all significantly affect the future development of the integration process. German unification would greatly alter both the relative strength of Helmut Kohl, the German Chancellor, and the attitude of his fellow European leaders towards German power. Germany's capacity to shape the new Europe, but also the determination of Germany's partners to construct a European framework powerful enough to contain what had become by some distance the EC's largest member state, were both increased markedly by the events of 1989 onward. ${ }^{34}$ The transformed geo-political environment meanwhile, characterised by uncertainty as much as opportunity, made that much more urgent the tasks of equipping Europe with new powers in both justice and home affairs, and foreign policy cooperation. ${ }^{35}$ In a wider Europe characterised by uncertainty and instability, the need had grown for a European Community better able to police its external borders, cope with influxes of refugees, or coordinate its foreign policy stance. And the mere possibility of further enlargement, first to Cold War neutrals like Sweden, Finland and Austria whose non-participation in the integration process

33. Britain's position as odd-one-out on European matters during this period was perhaps best captured by a famous Independent cartoon, dating from the run up to Maastricht, which portrayed John Major, Mrs Thatcher's successor, dressed for a game of his beloved cricket, walking onto a sports pitch where everyone else had clearly gathered to play football.

34. F. BOZO, Mitterrand, la fin de la guerre froide et l'unification allemande: de Yalta à Maastricht, O. Jacob, Paris, 2005.

35. For the multiple possibilities that opened up, but also for the conservatism of the choices eventually made, see M.E. SAROTTE, 1989: the struggle to create post-Cold War Europe, Princeton University Press, Princeton, N.J., 2009. 
made little sense in a post-Cold War world, and then, in the rather longer term, to the newly liberated countries of the former Soviet Bloc, highlighted still further the need to streamline the European decision-making processes and increase the efficiency of the institutions. As so often in Community history, the prospect of widening membership provided a significant incentive for the existing members to deepen integration before the newcomers arrived. The birth of the European Union is therefore inseparable from the transformed Europe that was emerging around it.

The basic agenda of what would become the Maastricht Treaty had, however, already been defined before these transformations came about. A Centre for European Policy Studies publication, finalised in January 1989 but therefore largely written in 1988, already listed the completion of the Single Market, EMU and progress towards 'a European External Identity' as the three priorities for the years ahead, and spoke of 'subsidiarity' and 'multiple strategies' (i.e. varying institutional formulae depending on policy area) as crucial characteristics of likely European advance. ${ }^{36}$ This clearly foreshadowed two of the three pillars of the eventual treaty, as well as two of the key underlying concepts. The subjects to which European leaders would have to address themselves, if not yet the outcomes of their deliberations, were thus largely determined by the pattern of Community development in the 1980s rather than by the geo-political earthquake from 1989 onwards.

36. P. LUDLOW, Beyond 1992. Europe and Its Western Partners, Centre for European Policy Studies, Brussels, 1989, esp. pp.61-84. 